Dr Dragoslav Ugarak, pukovnik, dipl. inž. Tehnički opitni centar, Beograd

\section{PRAĆENJE CILJA POMOĆU VIDEO SENZORA PRIMENOM ESTIMATORA SA VIŠE MODELA}

\author{
UDC: $623.4 .023: 621.397]: 519.87$
}

Rezime:

U radu je opisan matematički model praćenja cilja na osnovu određivanja uglova $i$ daljine cilja obradom video snimaka u toku praćenja. Izvršena je sinteza višemodelskog (MM) estimatora stanja na bazi Kalmanovih filtera i utvrđena tačnost estimacije i predikcije kretanja cilja na konkretnom primeru.

Ključne reči: praćenje cilja, estimacija i predikcija cilja, modeli kretanja cilja i multimodelski estimator.

\title{
TARGET TRACKING BY VIDEO SENSOR WITH MULTIPLE MODEL APPROACH
}

Summary:

This paper presents mathematical model of target tracking based on angle and target range determination by analyzing video frames during the tracking. The multiple model approach is performed using Kalman filter, and estimation and target motion prediction accuracy is determined using concrete example.

Key words: target tracking; models, estimation and prediction of target motion, and multiple model estimator.

\section{Uvod}

Automatsko praćenje ciljeva podrazumeva prikupljanje i obradu informacija o kretanju cilja bez neposrednog učešća čoveka. Takav vid upravljanja zahteva istraživačke rezultate koji su vezani za mnoge naučne oblasti, pre svega matematike, mehanike, optoelektronike, automatskog upravljanja i drugih. Integracijom tih rezultata razvijen je niz modela automatskog praćenja cilja video-sistemima, koji se mogu svrstati u dve osnovne grupe, a to su:

- sistemi za praćenje na osnovu odstupanja karakteristika koje su izdvojene iz slike cilja u odnosu na osu uređaja za praćenje,

- sistemi za praćenje na osnovu estimacije i predikcije pozicije cilja i parametara u odnosu na uređaj za praćenje.

Video-sistemi za praćenje ciljeva rade na bazi optoelektronskih kamera osetljivih na delove optičkog spektra elektromagnetnog zračenja. Po spektralnoj osetljivosti dele se na senzore vidljivog spektra ili televizijske kamere (TV) i senzore IC spektra ili termovizijske kamere (TTV). Ovi senzori formiraju svoje opservacije $u$ vidu video signala dvodimenzionalnih slika registrovanih u regularnim vremenskim intervalima (obično 
$40 \mathrm{~ms}$ ). Analizom formirane slike dobijaju se informacije o obeležjima cilja, kao što su vrsta cilja, srednji osvetljaj, boja, površina, dimenzije, dužina obvojnice (perimetar) cilja, koordinate karakterističnih tačaka cilja i drugi parametri.

Obradom signala sa senzora detektuje se cilj u vazdušnom prostoru i meri njegova pozicija. Izmereni položaj cilja sam po sebi ne određuje buduće kretanje cilja. Da bi se odredili parametri kretanja neophodno je da se pretpostavi ili detektuje način njegovog kretanja i matematički opišu procesi merenja i kretanja cilja. To predstavlja osnovu za matematički postupak određivanja parametara kretanja cilja i dovoljno precizno predviđanje njegovog budućeg položaja radi obezbeđivanja uslova za efikasno gađanje.

\section{Praćenje cilja na osnovu estimacije stanja}

Problem praćenja može se definisati kao problem određivanja parametara kretanja objekta u prostoru. Za realizaciju zadatka praćenja neophodno je ostvariti informacionu vezu sa objektom praćenja. To se ostvaruje sistemom senzora pomoću kojih se mere dostupni parametri. Da bi se u toku praćenja ostvarila neprekidna veza sa ciljem potrebno je vršiti usmeravanje vidnog polja senzora ka objektu praćenja. To znači da se praćenje sastoji od estimacije parametara kretanja cilja i od upravljanja kretanjem senzora radi usmeravanja ka objektu praćenja. Šematski prikaz postupka praćenja cilja na bazi estimacije njegovog stanja prikazan je na slici 1.

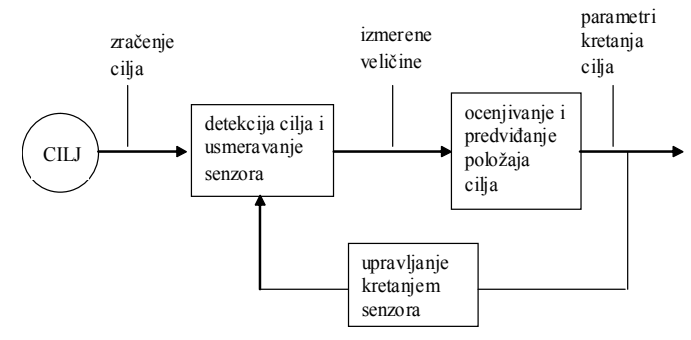

\section{Sl. 1 - Strukturna šema sistema praćenja cilja}

Matematički model praćenja cilja sastoji se od jednačine kretanja cilja i jednačine merenja. Priroda kretanja cilja i procesa merenja je takva da su modeli (jednačine) kretanja cilja i merenja uvek nelinearni, bez obzira na izbor vektora stanja i koordinatnih sistema u kojima se problem rešava. Matematički modeli kretanja cilja i merenja zajedno predstavljaju model praćenja cilja i dati su jednačinama:

$$
\begin{aligned}
& \dot{x}(t)=f(x(t), t)+g(x(t), t) v(t) \\
& z(t)=h(x(t), t)+w(t)
\end{aligned}
$$

gde je $\mathrm{x}(\mathrm{t})$ - vektor stanja dimenzije $\mathrm{n}_{\mathrm{x}}$, a $\mathrm{z}(\mathrm{t})$ - vektor merenja dimenzije $\mathrm{n}_{\mathrm{z}}$.

Vektor stanja $\mathrm{x}(\mathrm{t})$ je slučajni vektor za koji se pretpostavlja da ima početnu vrednost $\mathrm{x}(0)$ koja predstavlja Gausov proces sa poznatom srednjom vrednosti i kovarijansnom matricom:

$$
E[x(0)]=\hat{x}_{0}
$$

$$
E\left[\left(x_{0}-\hat{x}_{0}\right)\left(x_{0}-\hat{x}_{0}\right)^{T}\right]=P_{0}
$$

Vektor šuma procesa $\mathrm{v}(\mathrm{t})$ dimenzije $\mathrm{n}_{\mathrm{x}}$, je beli Gausov proces sa nultim matematičkim očekivanjem i kovarijansnom matricom: 


$$
E[v(t)]=0
$$

$$
E\left[\left(v(t) v(\tau)^{T}\right]=Q(t) \delta(t-\tau)\right.
$$

Vektor šuma merenja $w(t)$ dimenzije $n_{z}$ je beli Gausov proces sa nultim matematičkim očekivanjem i kovarijansnom matricom:

$$
E[w(t)]=0
$$

$$
E\left[\left(w(t) w(\tau)^{T}\right]=R(t) \delta(t-\tau)\right.
$$

Jednačine (1) i (2) ne predstavljaju opšti oblik modela praćenja cilja, jer sadrže hipoteze o aditivnosti šuma procesa i šuma merenja i o Gausovom karakteru šumova i početnog stanja, što a priori nije slučaj. Primena datih jednačina zahteva upotrebu metoda nelinearne estimacije koje su veoma složene i čija on-line primena nema praktičnog opravdanja. Zato se uvek pribegava linearizaciji modela praćenja, koja se vrši linearizacijom nelinearnih funkcija $\mathrm{f}, \mathrm{g} i \mathrm{~h}$.

Savremeni postupci praćenja zasnivaju se na upotrebi digitalnih računara, pa se model kretanja cilja i model merenja definišu u diskretnom vremenskom domenu. Cilj tokom vremena menja karakter svog kretanja pa se mora menjati i model njegovog kretanja ili parametri modela. To je postupak adaptacije modela kretanja cilja po kojem se realizuje praćenje.

\section{Primer merenja pozicije cilja sa video-snimaka}

Izvršeno je praćenje putanje borbenog aviona $\mathrm{G} 2$, koji je $\mathrm{u}$ toku leta sniman televizijskom kamerom. Merenje putanje cilja ovom prilikom izvršeno je pomoću dva teodolita sa automatskim praćenjem $\mathrm{u}$ toku leta da bi se dobila referentna putanja. Putanja aviona predstavlja let sa manevrom propinjanja u vertikalnoj ravni (slika 2).

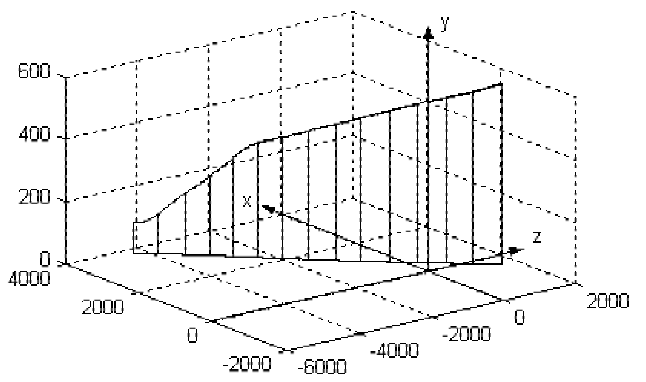

Sl. 2 - Putanja aviona G2 snimljena sa dva teodolita

Obradom snimaka sa TV kamere jednog teodolita koji je pratio let aviona, dobijene su vrednosti ugaonih odstupanja centra cilja od optičke ose teodolita i daljine cilja. Na osnovu koordinata karakteristične tačke cilja u ravni slike određuju se uglovna odstupanja azimuta i elevacije cilja u odnosu na optičku osu senzora, a pomoću tri ili više tačaka cilja poznatih dimenzija može se odrediti daljina cilja.

Uglovi linije viziranja cilja mere se tako što ugrađeni davači u uređaju za praćenje mere uglove azimuta $\left(\alpha_{\mathrm{s}}\right)$ i elevacije $\left(\beta_{\mathrm{s}}\right)$ nosača senzora koji ujedno predstavljaju uglove optičke ose video senzora. Uglovi azimuta $\left(\alpha_{s}\right)$ i elevacije $\left(\beta_{\mathrm{s}}\right)$ ose senzora mere se preciznim ugaonim davačima, obično apsolutnim optičkim enkoderima, $u$ koordinatnom sistemu uređaja za praćenje cilja. Obradom video slike određuju se uglovi azimuta $(\Delta \alpha)$ i elevacije $(\Delta \beta)$ linije viziranja cilja u odnosu na optičku osu senzora. Za ka- 
rakterističnu tačku viziranja cilja obično se bira težište (centar) cilja, jer je ono od najvećeg interesa za gađanje cilja, slika 3. Ugaona odstupanja centra cilja $\Delta \alpha$ i $\Delta \beta$ od optičke ose senzora srazmerna su odstupanjima centra cilja v i u od centra kadra C.

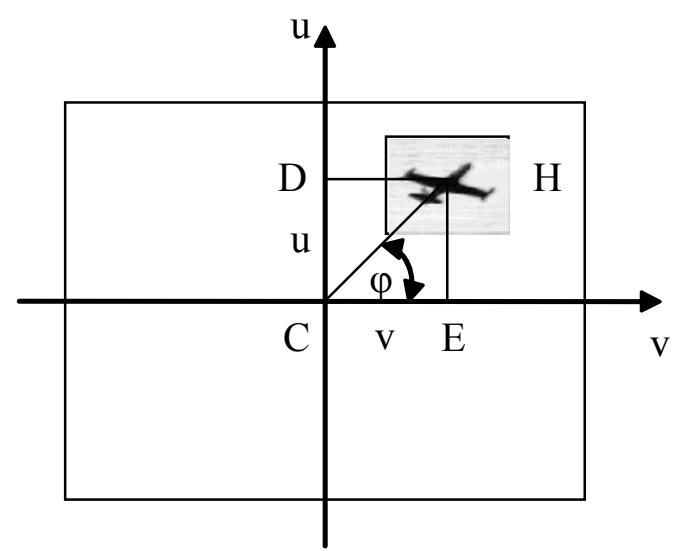

Sl. 3 - Položaj cilja u koordinatnom sistemu snimka

Za određivanje lokalnih uglova azimuta i elevacije linije viziranja cilja koriste se sledeće jednačine [1]:

$$
\begin{aligned}
& \alpha=\alpha_{s}+\Delta \alpha \\
& \beta=\beta_{s}+\Delta \beta
\end{aligned}
$$

Određivanje daljine cilja na osnovu poznavanja veličine cilja i koordinata karakterističnih tačaka (dna, vrha i krajeva krila) izvršeno je metodom lokacije trougla poznatih dužina stranica [2]. Promena daljine cilja u zavisnosti od vremena prikazana je na slici 4.

Vrednosti uglova azimuta i elevacije, dobijene očitavanjem snimaka, zbog malih vrednosti standardnih odstupanja, koriste se za estimaciju i predikciju kretanja cilja bez prethodnog uravnavanja. Za uravnavanje daljine cilja primenjen je
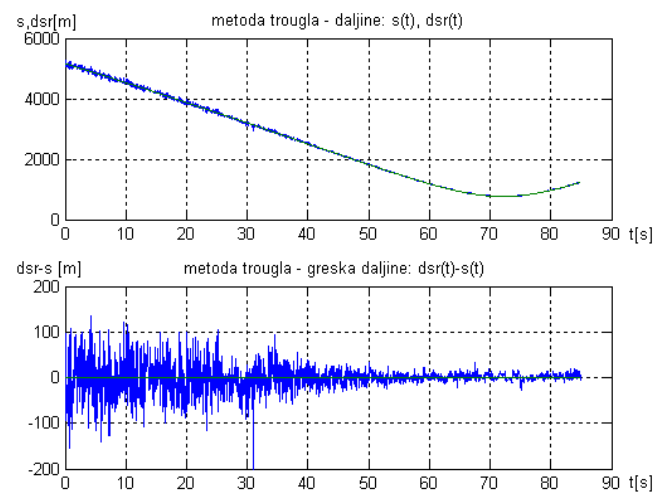
Sl. 4 - Daljina cilja određena sa snimaka
TV kamere

Kalmanov filter sa kinematskim modelom približno konstantnog ubrzanja i adaptacijom na promene šuma procesa [3]. Nakon estimacije znatno je smanjena greška ocene daljine cilja, što se vidi sa slike 5 .

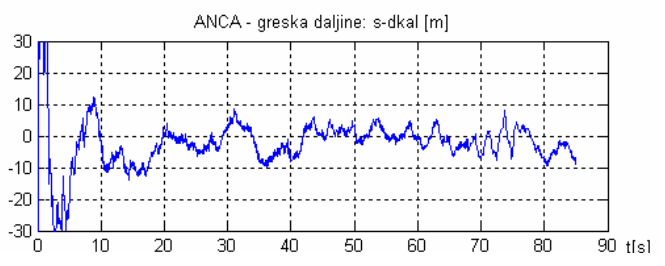

Sl. 5 - Grě̌ka estimacije daljine cilja

Skoro svi noviji postupci za ocenjivanje stanja koriste diskretni Kalmanov filter. On daje najpreciznije ocene stanja, pod uslovom da model cilja tačno opisuje njegovo kretanje, kao i da šumovi prisutni u modelima cilja i merenja predstavljaju bele šumove. Važna osobina Kalmanovog filtera je rekurzivnost koja omogućava racionalno korišćenje računarske memorije i kratko trajanje proračuna. To ga, ujedno, čini pogodnim za primenu u sistemima za upravljanje vatrom $[4,5,6]$. 


\section{Model kretanja cilja i model merenja}

$\mathrm{Na}$ osnovu podataka o uglovnoj poziciji i daljini cilja, dobijenih obradom video-snimaka, kao u prethodnom primeru, za potrebe praćenja i gađanja cilja potrebno je izvršiti estimaciju i predikciju njegovog kretanja. Iskustva pokazuju da su estimacija metodom najmanjih kvadrata $i$ Kalmanov filter [5, 6] opšteprihvaćene i uobičajene metode estimacije u savremenim sistemima za praćenje ciljeva. Posebno je pogodna primena sofisticiranih metoda Kalmanovog filtera na probleme praćenja visokomanevrišućih ciljeva.

Primena Kalmanovog filtera zahteva poznavanje modela kretanja cilja. Široko korišćeni su kinematski modeli izvedeni iz prostih jednačina kretanja sa konstantnom brzinom i konstantnim ubrzanjem [6]. Diskretna dinamička jednačina sistema je:

$$
x(k+1)=F(k) x(k)+\Gamma(k) v(k)
$$

Ovde je $\mathrm{x}(\mathrm{k})$ vektor stanja čiji elementi su pravougle koordinate, komponente brzine i ubrzanja cilja:

$$
\begin{aligned}
x & =\left[\begin{array}{lllllllll}
x_{1} & x_{2} & x_{3} & x_{4} & x_{5} & x_{6} & x_{7} & x_{8} & x_{9}
\end{array}\right]^{T}= \\
& =\left[\begin{array}{lllllllll}
x & \dot{x} & \ddot{x} & y & \dot{y} & \ddot{y} & z & \dot{z} & \ddot{z}
\end{array}\right]
\end{aligned}
$$

a $\mathrm{v}(\mathrm{k})$ je skalarna veličina šuma procesa, bela Gausova sekvenca nulte sredine, sa kovarijansom:

$$
E\left[v(k) v(j)^{T}\right]=Q(k) \delta_{k j}
$$

Za usvojeni model kretanja cilja matrice $\mathrm{F}(\mathrm{k}), \Gamma(\mathrm{k})$ i $\mathrm{Q}(\mathrm{k})$ su poznate i kasnije će biti prikazane za pojedine modele.
Jednačina diskretnih merenja glasi:

$z(k)=H(k) x(k)+w(k), \mathrm{k}=1,2, \ldots$

Ovde je $\mathrm{H}(\mathrm{k})$ matrica merenja, a w(k) je šum merenja, sekvenca belog Gausovog šuma sa nultom sredinom i kovarijansom:

$E\left[\left(w(k) w(j)^{T}\right]=R(k) \delta_{k j}\right.$

gde je $\delta_{\mathrm{kj}}$ Kronekerova (diskretna) delta funkcija:

$\delta_{k j}= \begin{cases}1, & k=j \\ 0 & k \neq j\end{cases}$

Ako se u toku praćenja cilja meri samo njegova pozicija, matrica merenja $\mathrm{H}$ glasi:

$H=\left[\begin{array}{lllllllll}1 & 0 & 0 & 0 & 0 & 0 & 0 & 0 & 0 \\ 0 & 0 & 0 & 1 & 0 & 0 & 0 & 0 & 0 \\ 0 & 0 & 0 & 0 & 0 & 0 & 1 & 0 & 0\end{array}\right]$

Pozicija cilja meri se u sfernim koordinatama $(\alpha, \beta, d)$, koje se nakon uravnavanja prevode $\mathrm{u}$ pravougle koordinate $(\mathrm{x}, \mathrm{y}, \mathrm{z})$.

Vektor merenja u sfernom koordinatnom sistemu i kovarijansna matrica grešaka merenja sfernih koordinata su:

$z=\left[\begin{array}{l}\alpha_{m} \\ \beta_{m} \\ d_{m}\end{array}\right]$

$R=\left[\begin{array}{ccc}\sigma_{\alpha}^{2} & 0 & 0 \\ 0 & \sigma_{\beta}^{2} & 0 \\ 0 & 0 & \sigma_{d}^{2}\end{array}\right]$ 
Greške merenja sfernih koordinata su međusobno i vremenski nekorelisani beli Gausovi šumovi nultih matematičkih očekivanja.

U primeru određivanja putanje cilja obradom video-snimaka izvršeno je uravnavanje daljine cilja pomoću Kalmanovog filtera sa dva kinematska modela, pri čemu je dobijeno da je tačnost određivanja daljine:

$$
\sigma_{d}=10 m
$$

Utvrđeno je da varijanse merenja ugaone pozicije cilja iznose:

$$
\begin{aligned}
& \sigma_{\alpha}^{2}=\sigma_{\alpha s}^{2}+\sigma_{\Delta \alpha}^{2}=10^{-6} \mathrm{rad}^{2}=1 \mathrm{mrad}^{2} \\
& \sigma_{\beta}^{2}=\sigma_{\beta s}^{2}+\sigma_{\Delta \beta}^{2}=10^{-6} \mathrm{rad}^{2}=1 \mathrm{mrad}^{2}
\end{aligned}
$$

Matrica kovarijansi merenja sfernih koordinata $u$ datom primeru ne zavisi od vremena i iznosi:

$$
R=\left[\begin{array}{ccc}
10^{-6} & 0 & 0 \\
0 & 10^{-6} & 0 \\
0 & 0 & 10^{2}
\end{array}\right]
$$

Greške merenja sfernih koordinata su međusobno i vremenski nekorelisani beli Gausovi šumovi nultih matematičkih očekivanja.

Pravougle koordinate putanje cilja $\mathrm{u}$ lokalnom zemaljskom koordinatnom sistemu date su jednačinama:

$$
\begin{aligned}
& x=d \cos \beta \cos \alpha \\
& y=d \sin \beta \\
& z=d \cos \beta \sin \alpha
\end{aligned}
$$

Greške određivanja koordinata (x, y, z) mogu se, razvojem jednačina (19) u Tejlorov red, dobiti u vidu linearne zavisnosti od grešaka merenja polarnih koordinata $(\alpha, \beta, d)$. Za određivanje matrice kovarijansi grešaka merenja u pravouglim koordinatama može se tada upotrebiti relacija:

$R_{x}=D R D^{T}$

gde su:

$R_{x}=\left[\begin{array}{ccc}\sigma_{x}^{2} & \sigma_{x y}^{2} & \sigma_{x z}^{2} \\ \sigma_{x y}^{2} & \sigma_{y}^{2} & \sigma_{y z}^{2} \\ \sigma_{x z}^{2} & \sigma_{y z}^{2} & \sigma_{y}^{2}\end{array}\right]$

$D=\frac{\partial(x, y, z)}{\partial(\alpha, \beta, d)}=\left[\begin{array}{lll}\frac{\partial x}{\partial \alpha} & \frac{\partial x}{\partial \beta} & \frac{\partial x}{\partial d} \\ \frac{\partial y}{\partial \alpha} & \frac{\partial y}{\partial \beta} & \frac{\partial y}{\partial d} \\ \frac{\partial z}{\partial \alpha} & \frac{\partial z}{\partial \beta} & \frac{\partial z}{\partial d}\end{array}\right]$

Rešavanjem matrične jednačine (22) dobija se:

$\sigma_{x}^{2}=z^{2} \sigma_{\alpha}^{2}+\frac{x^{2} y^{2}}{x^{2}+z^{2}} \sigma_{\beta}^{2}+\frac{x^{2}}{d^{2}} \sigma_{d}^{2}$

$\sigma_{y}^{2}=\left(x^{2}+z^{2}\right) \sigma_{\beta}^{2}+\frac{y^{2}}{d^{2}} \sigma_{d}^{2}$

$\sigma_{z}^{2}=x^{2} \sigma_{\alpha}^{2}+\frac{y^{2} z^{2}}{x^{2}+z^{2}} \sigma_{\beta}^{2}+\frac{z^{2}}{d^{2}} \sigma_{d}^{2}$

$\sigma_{x y}^{2}=-x y \sigma_{\beta}^{2}+\frac{x y}{d^{2}} \sigma_{d}^{2}$

$\sigma_{x z}^{2}=-x z \sigma_{\alpha}^{2}+x z \frac{y^{2}}{x^{2}+z^{2}} \sigma_{\beta}^{2}+\frac{x z}{d^{2}} \sigma_{d}^{2}$

$\sigma_{y z}^{2}=-y z \sigma_{\beta}^{2}+\frac{y z}{d^{2}} \sigma_{d}^{2}$ 
Greške određivanja pravouglih koordinata su beli Gausovi šumovi nultih matematičkih očekivanja koji nisu vremenski korelisani, ali jesu međusobno. Varijanse i kovarijanse pravouglih koordinata date su jednačinama (23), kao funkcije merenih pravouglih koordinata $\left(\mathrm{x}_{\mathrm{m}}, \mathrm{y}_{\mathrm{m}}, \mathrm{z}_{\mathrm{m}}\right)$ i varijansi merenih sfernih koordinata.

\section{Predikcija kretanja cilja i ocena efikasnosti praćenja}

Rešavanje problema estimacije stanja objekta praćenja odnosi se na objekte poznatih manevarskih sposobnosti. Njegovo kretanje opisuje se stohastičkim diferencijalnim jednačinama, čime je obuhvaćeno delovanje slučajnih ili organizovanih smetnji. Polazeći od diskretnih stohastičkih merenja jednog broja veličina stanja objekta praćenja potrebno je, u realnom vremenu, odrediti vektor stanja objekta praćenja. Pored toga, potrebno je predvideti buduće ponašanje objekta praćenja (predikcija stanja).

Predikcija je estimacija stanja u trenutku $\mathrm{m}$ posle raspoloživog intervala podataka $\mathrm{k}<\mathrm{m}$. U sistemima upravljanja vatrom PVO primenjuje se predikcija kretanja cilja u pokretnoj tački koja je za L koraka posle trenutne tačke merenja $\mathrm{k}$, pri čemu veličina intervala L odgovara vremenu preticanja cilja:

$\hat{x}(k+L / k)=\left[\prod_{j=0}^{L-1} F(k+L-1-j)\right] \hat{x}(k / k)$

U slučaju povremenih prekida merenja, na primer zbog trenutnog gubljenja cilja u toku praćenja, da bi se sprečio prekid praćenja, estimacija vektora stanja zamenjuje se predikcijom. Dakle, kada privremeno izostane merenje pozicije cilja, praćenje kretanja cilja odvija se na osnovu predikcije njegove pozicije koja se računa korak po korak, do ponovnog uspostavljanja merenja.

Izlazna veličina postupka praćenja ili estimacije kretanja cilja je ocena vektora stanja koja sadrži ocene koordinata cilja, komponenti brzine i ubrzanja. Te veličine koriste se za predviđanje položaja cilja, odnosno tačke susreta projektila i cilja. Verovatnoća pogađanja cilja zavisi od tačnosti ocena navedenih kinematskih veličina. Za ocenjivanje efikasnosti praćenja cilja mogu se posmatrati sledeće veličine:

1. Greška ocene pozicije cilja:

$$
\begin{aligned}
& e_{p o z}(t)= \\
& \sqrt{[x(t)-\hat{x}(t)]^{2}+[y(t)-\hat{y}(t)]^{2}+[z(t)-\hat{z}(t)]^{2}}
\end{aligned}
$$

2. Greška predikcije cilja:

$$
\begin{aligned}
& e_{p r e}(t)= \\
& \sqrt{\left[x(t)-x_{p}(t)\right]^{2}+\left[y(t)-y_{p}(t)\right]^{2}+\left[z(t)-z_{p}(t)\right]^{2}}
\end{aligned}
$$

3. Standardno odstupanje pozicije cilja:

$$
\sigma_{p o z}(t)=\sqrt{\frac{1}{N-1} \sum_{i=1}^{N}\left[e_{p o z}(t)-e_{p o z s r}(t)\right]^{2}}
$$
cilja:

4. Standardno odstupanje predikcije

$$
\sigma_{\text {pre }}(t)=\sqrt{\frac{1}{N-1} \sum_{i=1}^{N}\left[e_{\text {pre }}(t)-e_{\text {prest }}(t)\right]^{2}}
$$


U datom primeru srednja daljina aviona je $2,5 \mathrm{~km}$, čemu odgovara vreme leta projektila oko $3 \mathrm{~s}$. Zato će predikcija vektora stanja biti određena za $\mathrm{L}=75$ tačaka. Standardna odstupanja ocene pozicije cilja i predikcije pozicije cilja biće određena za sredinu intervala od $\mathrm{N}=100$ tačaka, koji će biti pomeran za po jednu tačku unapred u toku praćenja cilja.

\section{Hipoteze o kretanju cilja}

Najsloženije kretanje ciljeva koji lete izvode avioni. Ono je složena funkcija performansi letelice, veštine pilota, taktike napada, slučajnih poremećaja i slično. Zato je nemoguće precizno opisati proizvoljno kretanje cilja bez poznavanja veličine upravljačkih parametara, aerodinamičkih i pogonskih parametara letelice, stanja atmosfere i dejstva slučajnih poremećaja. Međutim, postoje posebni slučajevi leta cilja koji se mogu precizno matematički opisati uprošćenim modelima u kojima se ne pojavljuju nepoznate veličine. To su ustaljeni režimi leta koji se primenjuju tokom većeg dela vremena leta aviona, dok se promena načina kretanja vrši u neustaljenom režimu leta, takozvanim manevrom. Na osnovu toga uvode se sledeće hipoteze o kretanju cilja:

- hipoteza o pravolinijskom letu konstantnom brzinom;

- hipoteza o letu sa konstantnim vektorom ubrzanja;

- hipoteza o neustaljenom režimu leta.

Ove hipoteze omogućavaju da se uvedu sledeći matematički modeli kretanja cilja: $(\mathrm{NCV})$

- model približno konstantne brzine

- model približno konstantnog ubrzanja (NCA):
- model eksponencijalno korelisanog ubrzanja (ECA).

Prva dva modela predstavljaju ustaljeno kretanje cilja i omogućavaju precizno praćenje i predviđanje tačke susreta cilja i projektila. Treći model predstavlja neustaljeno kretanje cilja (manevar) i omogućava precizno pozicioniranje senzora i stabilno praćenje cilja, ali manje precizno predviđanje tačke susreta.

Režimi kretanja cilja su procesi slučajnog karaktera, tako da je neizvesno koliko vremena i po kojoj od datih hipoteza će se cilj kretati. Osnovni problem jeste da se u toku praćenja odredi po kojoj hipotezi se odvija kretanje cilja. To se rešava određivanjem verovatnoće tačnosti pojedinih hipoteza kretanja cilja u toku praćenja i primenom najverovatnijeg modela.

\section{Model približno konstantne brzine}

Model približno konstantne brzine podrazumeva da su male promene brzine kretanja cilja date kao beli šum procesa sa nultom srednjom vrednosti u toku perioda uzorkovanja $T$. Jednačina stanja modela približno konstantne brzine za jednu koordinatu prikazana je u [3]. Proširivanjem tih jednačina na tri koordinate dobijaju se sledeće matrice:

$\mathrm{F}=\left[\begin{array}{lllllllll}1 & \mathrm{~T} & 0 & 0 & 0 & 0 & 0 & 0 & 0 \\ 0 & 1 & 0 & 0 & 0 & 0 & 0 & 0 & 0 \\ 0 & 0 & 0 & 0 & 0 & 0 & 0 & 0 & 0 \\ 0 & 0 & 0 & 1 & \mathrm{~T} & 0 & 0 & 0 & 0 \\ 0 & 0 & 0 & 0 & 1 & 0 & 0 & 0 & 0 \\ 0 & 0 & 0 & 0 & 0 & 0 & 0 & 0 & 0 \\ 0 & 0 & 0 & 0 & 0 & 0 & 1 & \mathrm{~T} & 0 \\ 0 & 0 & 0 & 0 & 0 & 0 & 0 & 1 & 0 \\ 0 & 0 & 0 & 0 & 0 & 0 & 0 & 0 & 0\end{array}\right]$


$Q=S v\left[\begin{array}{ccccccccc}\frac{T^{4}}{4} & \frac{T^{3}}{2} & 0 & 0 & 0 & 0 & 0 & 0 & 0 \\ \frac{T^{3}}{2} & T^{2} & 0 & 0 & 0 & 0 & 0 & 0 & 0 \\ 0 & 0 & 0 & 0 & 0 & 0 & 0 & 0 & 0 \\ 0 & 0 & 0 & \frac{T^{4}}{4} & \frac{T^{3}}{2} & 0 & 0 & 0 & 0 \\ 0 & 0 & 0 & \frac{T^{3}}{2} & T^{2} & 0 & 0 & 0 & 0 \\ 0 & 0 & 0 & 0 & 0 & 0 & 0 & 0 & 0 \\ 0 & 0 & 0 & 0 & 0 & 0 & \frac{T^{4}}{4} & \frac{T^{3}}{2} & 0 \\ 0 & 0 & 0 & 0 & 0 & 0 & \frac{T^{3}}{2} & T^{2} & 0 \\ 0 & 0 & 0 & 0 & 0 & 0 & 0 & 0 & 0\end{array}\right]$

$S v=\left[\begin{array}{ccccccccc}\sigma_{v x}^{2} & 0 & 0 & 0 & 0 & 0 & 0 & 0 & 0 \\ 0 & \sigma_{v x}^{2} & 0 & 0 & 0 & 0 & 0 & 0 & 0 \\ 0 & 0 & \sigma_{v x}^{2} & 0 & 0 & 0 & 0 & 0 & 0 \\ 0 & 0 & 0 & \sigma_{v y}^{2} & 0 & 0 & 0 & 0 & 0 \\ 0 & 0 & 0 & 0 & \sigma_{v y}^{2} & 0 & 0 & 0 & 0 \\ 0 & 0 & 0 & 0 & 0 & \sigma_{v y}^{2} & 0 & 0 & 0 \\ 0 & 0 & 0 & 0 & 0 & 0 & \sigma_{v z}^{2} & 0 & 0 \\ 0 & 0 & 0 & 0 & 0 & 0 & 0 & \sigma_{v z}^{2} & 0 \\ 0 & 0 & 0 & 0 & 0 & 0 & 0 & 0 & \sigma_{v z}^{2}\end{array}\right]$

Varijanse šuma procesa $\sigma_{v x}^{2}, \sigma_{v y}^{2} \mathrm{i}$ $\sigma_{v z}^{2}$ određuju se saglasno veličini komponenti srednjeg ubrzanja po koordinatama:

$a_{s r(x, y, z)}=\frac{\Delta V_{(x, y, z)}}{T}$

Nakon inicijalizacije Kalmanovog filtera usvaja se niža vrednost šuma $\sigma_{v(x, y, z)}^{2}=1$, a zatim se posle izračunavanja prve vrednosti komponenti srednjeg ubrzanja, u kliznom prozoru od 50 tačaka, uvodi nova vrednost za varijansu šuma procesa po obrascu:

$$
\sigma_{v(x, y, z)}^{2}=10 a_{s r(x, y, z)}
$$

Ove vrednosti se neprestano određuju pomeranjem kliznog prozora korak po korak do kraja praćenja, tako da se nivo šuma procesa, koji se definiše pomoću varijansi, neprekidno prilagođava promenama ubrzanja cilja. Faktor uvećanja srednjeg ubrzanja od 10 puta u formuli (33) određen je eksperimentalno, tako da se dobije najmanja greška estimacije i predikcije cilja. Veće uvećanje varijanse šuma povećava oscilatornost procesa i uvećava grešku predikcije. Smanjenje nivoa šuma (vrednosti varijanse) smanjuje oscilatornost procesa, ali uvećava greške estimacije i predikcije. Početne vrednosti varijansi od $\sigma_{v(x, y, z)}^{2}=1$ ne utiču bitno na greške estimacije i predikcije u toku praćenja i neznatno utiču na prelazni proces u početku rada estimatora.

\section{Model približno konstantnog ubrzanja}

Ovaj model podrazumeva da se $u$ toku perioda uzorkovanja T ubrzanje cilja uvećava za vrednost šuma procesa $\mathrm{v}(\mathrm{t})$, koji je beli šum sa nultom srednjom vrednosti. Jednačine ovog modela za jednu koordinatu izvedene su u [3], a proširivanje modela na kretanje cilja u prostoru 3D može se ostvariti uvođenjem sledećih vrednosti matrica:

$F=\left[\begin{array}{ccccccccc}1 & T & T^{2} / 2 & 0 & 0 & 0 & 0 & 0 & 0 \\ 0 & 1 & T & 0 & 0 & 0 & 0 & 0 & 0 \\ 0 & 0 & 1 & 0 & 0 & 0 & 0 & 0 & 0 \\ 0 & 0 & 0 & 1 & T & T^{2} / 2 & 0 & 0 & 0 \\ 0 & 0 & 0 & 0 & 1 & T & 0 & 0 & 0 \\ 0 & 0 & 0 & 0 & 0 & 1 & 0 & 0 & 0 \\ 0 & 0 & 0 & 0 & 0 & 0 & 1 & T & T^{2} / 2 \\ 0 & 0 & 0 & 0 & 0 & 0 & 0 & 1 & T \\ 0 & 0 & 0 & 0 & 0 & 0 & 0 & 0 & 1\end{array}\right]$




$$
Q=S v\left[\begin{array}{ccccccccc}
\frac{T^{4}}{4} & \frac{T^{3}}{2} & \frac{T^{2}}{2} & 0 & 0 & 0 & 0 & 0 & 0 \\
\frac{T^{3}}{2} & T^{2} & T & 0 & 0 & 0 & 0 & 0 & 0 \\
\frac{T^{2}}{2} & T & 1 & 0 & 0 & 0 & 0 & 0 & 0 \\
0 & 0 & 0 & \frac{T^{4}}{4} & \frac{T^{3}}{2} & \frac{T^{2}}{2} & 0 & 0 & 0 \\
0 & 0 & 0 & \frac{T^{3}}{2} & T^{2} & T & 0 & 0 & 0 \\
0 & 0 & 0 & \frac{T^{2}}{2} & T & 1 & 0 & 0 & 0 \\
0 & 0 & 0 & 0 & 0 & 0 & \frac{T^{4}}{4} & \frac{T^{3}}{2} & \frac{T^{2}}{2} \\
0 & 0 & 0 & 0 & 0 & 0 & \frac{T^{3}}{2} & T^{2} & T \\
0 & 0 & 0 & 0 & 0 & 0 & \frac{T^{2}}{2} & T & 1
\end{array}\right]
$$

Ovde je $S_{v}$ matrica varijansi šumova procesa po koordinatama $\mathrm{S}_{\mathrm{v}}=\mathrm{f}\left(\sigma_{v x}^{2}, \sigma_{v y}^{2}, \sigma_{v z}^{2}\right)$ data relacijom (31).

Vrednosti varijansi šuma procesa određuju se saglasno promeni komponenti srednjeg ubrzanja $\Delta \mathrm{a}_{\mathrm{sr}(\mathrm{x}, \mathrm{y}, \mathrm{z})}$ koje se određuju prema [3]. Pri tome se varijanse računaju kao:

$$
\sigma_{v(x, y, z)}^{2}=0,001 \Delta a_{s r(x, y, z)}
$$

Vrednosti za priraštaj ubrzanja $\Delta \mathrm{a}_{\mathrm{sr}(\mathrm{x}, \mathrm{y}, \mathrm{z})}$ neprestano se računaju u pokretnom kliznom prozoru od 50 tačaka. Vrednost konstante kojom se množi prirast ubrzanja od 0,001 određena je eksperimentalno, tako da se dobijaju najmanje greške estimacije i predikcije pozicije cilja. Usvojeno je da početna vrednost varijanse šuma iznosi 0,01 . Uticaj promene vrednosti varijansi šuma procesa na tačnost estimacije i predikcije sličan je kao u prethodnom slučaju.

\section{Model sa promenljivim ubrzanjem}

Prethodni modeli dobro aproksimiraju ustaljene režime kretanja cilja sa konstantnom brzinom ili ubrzanjem, ali ne mogu dobro da aproksimiraju neustaljeno kretanje kada cilj vrši manevar. Za ciljeve koji manevrišu obično se koristi model sa eksponencijalno korelisanim ubrzanjem [5, 6]. Kretanje cilja sa manevrom u prostoru 3D može se modelirati uvođenjem sledećih vrednosti matrica:

$$
Q=S v\left[\begin{array}{ccccccccc}
\frac{T^{5}}{20} & \frac{T^{4}}{8} & \frac{T^{3}}{6} & 0 & 0 & 0 & 0 & 0 & 0 \\
\frac{T^{4}}{8} & \frac{T^{3}}{3} & \frac{T^{2}}{2} & 0 & 0 & 0 & 0 & 0 & 0 \\
\frac{T^{3}}{6} & \frac{T^{2}}{2} & T & 0 & 0 & 0 & 0 & 0 & 0 \\
0 & 0 & 0 & \frac{T^{5}}{20} & \frac{T^{4}}{8} & \frac{T^{3}}{6} & 0 & 0 & 0 \\
0 & 0 & 0 & \frac{T^{4}}{8} & \frac{T^{3}}{3} & \frac{T^{2}}{2} & 0 & 0 & 0 \\
0 & 0 & 0 & \frac{T^{3}}{6} & \frac{T^{2}}{2} & T & 0 & 0 & 0 \\
0 & 0 & 0 & 0 & 0 & 0 & \frac{T^{5}}{20} & \frac{T^{4}}{8} & \frac{T^{3}}{6} \\
0 & 0 & 0 & 0 & 0 & 0 & \frac{T^{4}}{8} & \frac{T^{3}}{3} & \frac{T^{2}}{2} \\
0 & 0 & 0 & 0 & 0 & 0 & \frac{T^{3}}{6} & \frac{T^{2}}{2} & \frac{T}{2}
\end{array}\right]
$$

Ovde je $S_{v}$ matrica varijansi šumova procesa po koordinatama $\mathrm{S}_{\mathrm{v}}=\mathrm{f}\left(\sigma_{v x}^{2}, \sigma_{v y}^{2}\right.$, $\sigma_{v z}^{2}$ ), data relacijom (31). 
Vrednosti varijansi šuma procesa kod ovog modela određuju se proporcionalno sa kvadratom ubrzanja, tako da je:

$$
\sigma_{v(x, y, z)}^{2}=0,15 \Delta a_{s r(x, y, z)}^{2}
$$

Vrednosti za priraštaj ubrzanja $\Delta \mathrm{a}_{\mathrm{sr}(\mathrm{x}, \mathrm{y}, \mathrm{z})}$ neprestano se računaju u pokretnom kliznom prozoru od 50 tačaka. Faktor proporcionalnosti 0,15 određen je eksperimentalno. Usvojeno je da početna vrednost varijanse šuma iznosi 0,15 . Uticaj promene vrednosti varijansi šuma procesa na tačnost estimacije i predikcije sličan je kao u prethodnim slučajevima.

\section{Estimacija primenom više modela}

U ovom pristupu sistem se ponaša po jednom od konačnog broja modela. Pri tome se koristi Bajesova formula za određivanje verovatnoće modela. $\mathrm{Na}$ osnovu Bajesovih rezultata svaki model startuje sa apriornom verovatnoćom, a odgovarajuće posteriorne verovatnoće izračunavaju se pri svakom koraku rada estimatora.

Ovde će se primeniti statički slučaj, kada je ponašanje pojedinih estimatora nezavisno od rezultata drugih estimatora, a rezultujuća izlazna estimacija dobija se kao suma pojedinih estimacija pomnoženih sa njihovim verovatnoćama.

Sistem u toku vremena može da menja model ponašanja, ali se u svakom trenutku ponaša po jednom od $n$ poznatih modela:

$$
\begin{gathered}
x(k+1)=F_{j}(k) x(k)+\Gamma_{j}(k) v_{j}(k), \\
j=1,2, . ., n
\end{gathered}
$$

Ovde je $\mathrm{x}(\mathrm{k})$ stanje sistema, a $\mathrm{v}_{\mathrm{j}}(\mathrm{k})$ su Gausovi beli šumovi procesa sa kovarijansama $\mathrm{Q}_{\mathrm{j}}(\mathrm{k})$.

Hipoteza da se sistem u nekom trenutku ponaša prema j-tom modelu označava se sa Mj. Verovatnoća da je hipoteza tačna iznosi:

$\mu_{j}(k)=\operatorname{Pr}\left\{M j \mid Z^{k}\right\}$

gde je $Z^{k}$ realizovana vremenska sekvenca merenja do trenutka $t_{k}=k T$ :

$Z^{k}=\{z(0), z(1), \ldots, z(k)\}$

Merenja su definisana opservacionim modelom:

$z(k)=H(k) x(k)+w(k)$

gde je w(k) Gausov beli šum kovarijanse $\mathrm{R}(\mathrm{k})$.

Početna verovatnoća da je tačna hipoteza $\mathrm{Mj}$, iznosi:

$\mu_{j}(0)=\operatorname{Pr}\left\{M j \mid Z^{0}\right\}$

Pri tome je očigledno da važi:

$\sum_{j=1}^{n} \mu_{j}(0)=1$

Primenom Bajesove formule [6] uslovna verovatnoća da je hipoteza $\mathrm{Mj}$ tačna može se izraziti u sledećem obliku:

$\mu_{j}(k)=\frac{\Lambda_{j}(k) \mu_{j}(k-1)}{\sum_{i=1}^{n} \Lambda_{i}(k) \mu_{i}(k-1)}$ 
Ovde je $\Lambda_{\mathrm{j}}(\mathrm{k})$ funkcija verodostojnosti modela $\mathrm{Mj} \mathrm{u}$ trenutku $\mathrm{t}_{\mathrm{k}}$, koja je za linearni Gausov model data sa:

$$
\begin{aligned}
\Lambda_{j}(k) & =f\left(z(k) \mid Z^{k-1}, M j\right) \\
& =f\left(y_{j}(k)\right)=\mathrm{N}\left\{y_{j}(k) ; 0, S_{j}(k)\right\}
\end{aligned}
$$

gde su $y_{j}$ i $S_{j}$ inovacija i njena kovarijansa za filter koji odgovara modelu $\mathrm{Mj}$, a $\mathrm{f}($.$) je funkcija gustine raspodele inovaci-$ je, koja ima normalnu raspodelu.

Rekurzivno izračunavanje verovatnoće modela počinje sa datom početnom verovatnoćom (44), za koju se obično uzima da iznosi $1 / n$, i nastavlja se pomoću (46) za $k=1,2, \ldots$ Pri tome se funkcija verodostojnosti određuje pomoću formule:

$$
\Lambda_{j}(k)=\frac{\exp \left[-0,5 y_{j}(k)^{T} S_{j}(k)^{-1} y_{j}(k)\right]}{\left\{(2 \pi)^{n_{z}} \operatorname{det}\left[S_{j}(k)\right]\right\}^{1 / 2}}
$$

Izlaz svakog filtera je modelom uslovljena ocena stanja $\hat{x}_{j}(k / k)$ sa kovarijansom $\mathrm{P}_{\mathrm{j}}(\mathrm{k} / \mathrm{k})$ i funkcijom verodostojnosti $\Lambda_{\mathrm{j}}(\mathrm{k})$.

Pod pretpostavkom da je funkcija gustine raspodele verovatnoća stanja sistema Gausova miksovana od n izlaza:

$$
\begin{aligned}
& f\left(x(k) \mid Z^{k}\right)= \\
& =\sum_{j=1}^{n} \mu_{j}(k) \mathrm{N}\left\{x(k) ; \hat{x}_{j}(k / k), P_{j}(k / k)\right\}
\end{aligned}
$$

kombinacija modelom uslovljenih ocena stanja i matrica kovarijansi kombinovane ocene iznosi: $\hat{x}(k / k)=\sum_{j=1}^{n} \mu_{j}(k) \hat{x}_{j}(k / k)$

$$
\begin{aligned}
& P(k / k)=\sum_{j=1}^{n} \mu_{j}(k)\left\{P_{j}(k / k)+\right. \\
& {\left[\hat{x}_{j}(k / k)-\hat{x}(k / k)\right]\left[\hat{x}_{j}(k / k)-\right.} \\
& \left.-\hat{x}(k / k]^{T}\right\}
\end{aligned}
$$

Dati izrazi su tačni pod pretpostavkama da se tačan model nalazi unutar skupa razmatranih modela i da su od početnog vremena na snazi isti modeli. Prva pretpostavka je razumljiva aproksimacija, dok druga nije tačna za promenljive modele, jer kada počne manevar dolazi do promene modela i tada se javljaju skokovi sa modela na model. U slučaju prebacivanja modela mogu se uvesti veštačke verovatnoće modela po određenom kriterijumu.

Ovaj pristup daje konzistentne estimacije ako skup modela uključuje pravi model, tako da nema skokova sa modela na model. Tada verovatnoća tačnog modela konvergira ka jedinici.

Primenom izložene metode urađen je MM estimator sa kinematskim modelima približno konstantne brzine (NCV), približno konstantnog ubrzanja (NCA) i eksponencijalno korelisanog ubrzanja (ECA), sa prethodno usvojenim parametrima koji se ne menjaju u toku praćenja cilja.

\section{Primer estimacije kretanja cilja sa više modela}

Pri kretanju cilja, u opštem slučaju, dolazi do slučajne promene režima leta. Pri tome se u svakom trenutku cilj kreće po jednom od opisanih ustaljenih režima 
ili po neustaljenom režimu. Modeli približno konstantne brzine i približno konstantnog ubrzanja dovoljno precizno opisuju ustaljeno kretanje cilja, dok model eksponencijalno korelisanog ubrzanja približno opisuje neustaljeno kretanje cilja. Da bi praćenje cilja bilo stabilno, a njegova predikcija pozicije što tačnija, uvek kada promeni način kretanja mora se promeniti i model koji opisuje kretanje cilja. Postoji više načina prilagođavanja modela praćenja kretanja cilja. To su promena parametara jedinstvenog modela cilja ili promena modela i parametara praćenja. U opštem slučaju, promena načina kretanja cilja nije poznata, pa se pribegava istovremenoj primeni više modela kretanja cilja paralelnom upotrebom više Kalmanovih filtera. To su takozvani estimatori sa više modela (MM - multimodel), statičkog ili dinamičkog tipa, koji određuju verovatnoću za svaki paralelno spregnuti model sa kojom modeli aproksimiraju trenutno kretanje cilja. Izlazne estimacije stanja i kovarijanse kod MM estimatora su sume estimacija pojedinih modela, pomnožene njihovim verovatnoćama.

Za eksperiment praćenja aviona, obrađen kroz primere $\mathrm{u}$ ovom radu, radi prikaza mogućnosti estimacije i predikcije kretanja cilja za potrebe praćenja i preticanja, urađen je statički multimodel estimator sa paralelno spregnuta tri Kalmanova filtera na osnovu prethodno opisanih modela (NCV, ACV i ECA). Kod statičkog MM estimatora nakon inicijalizacije filteri rade paralelno sa svojim jedinstvenim estimacijama stanja cilja. Verovatnoće da se cilj kreće saglasno nekom od primenjenih modela određuju se primenom Bajesove teoreme pomoću funkcija verodostojnosti (46). Izlazne vrednosti ocene vektora stanja i odgovarajuće kovarijanse dobijaju se sabiranjem ocena veličina stanja ili kovarijansi pojedinih filtera pomnoženih sa verovatnoćama njihove realizacije, kao što je dato jednačinama (50) i (51).

Rezultati paralelnog proračuna za sva tri modela prikazani su u vidu dijagrama na slici 6 , koji prikazuju greške estimacije i greške predikcije pozicije cilja u odnosu na referentnu putanju. $\mathrm{Na}$ slici 7 dati su dijagrami greške estimacije i predikcije pozicije i standardna odstupanja za MM estimator i verovatnoće modela. Vidi se da je najverovatniji model približno konstantne brzine, što odgovara prirodi kretanja cilja u datom primeru.
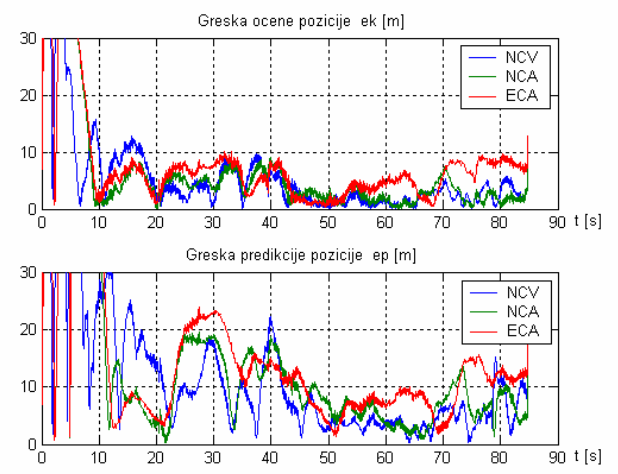

Sl. 6-Greške estimacije i predikcije pozicije za tri modela kretanja cilja

Rezultati paralelnog proračuna za sva tri modela prikazani su u vidu dijagrama na slici 6 , koji prikazuju greške estimacije i greške predikcije pozicije cilja u odnosu na referentnu putanju. Na slici 7 dati su dijagrami greške estimacije i predikcije pozicije i standardna odstupanja za MM estimator i verovatnoće modela. Vidi 
se da je najverovatniji model približno konstantne brzine, što odgovara prirodi kretanja cilja u datom primeru.
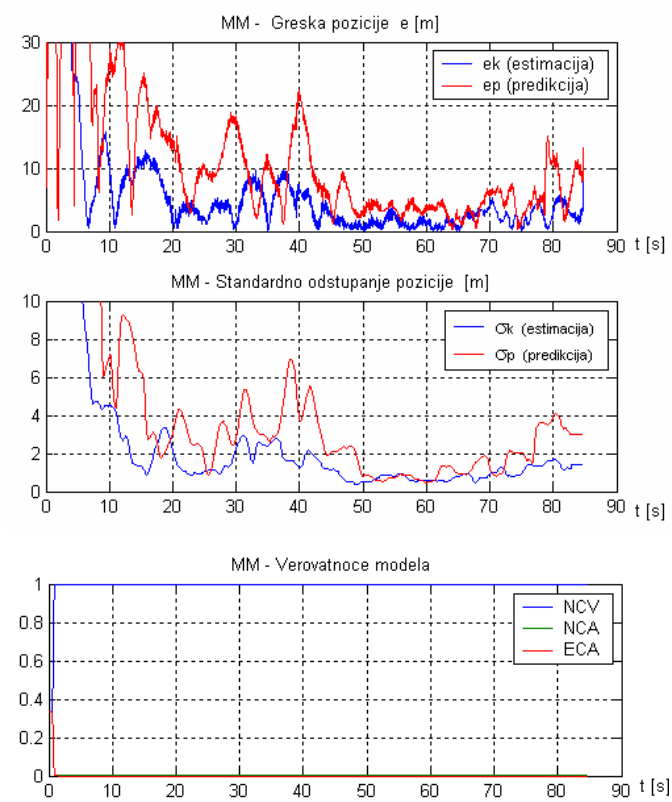

Sl. 7 - Greške estimacije i predikcije pozicije i standardna odstupanja za MM estimator

\section{Zaključak}

U radu je izvršena sinteza estimatora za estimaciju i predikciju kretanja cilja na osnovu obrade podataka praćenja cilja pomoću video senzora. Pri tome su primenjena tri modela kretanja cilja, sa približno konstantnom brzinom (NCV), približno konstantnim ubrzanjem (NCA) i model sa eksponencijalno korelisanim ubrzanjem (ECA), koji predstavlja manevrišući cilj. Kao konačno rešenje predložen je višemodelski (MM) estimator od tri paralelna Kalmanova filtera (NCV, NCA i ECA) sa kombinovanim izlaznim estimacijama i predikcijama kretanja cilja. Usvojeni su modeli sa devet veličina stanja, po tri pravougle koordinate cilja, komponente brzine i ubrzanja. Merene veličine su pravougle koordinate cilja, koje se dobijaju iz filtriranih sfernih koordinata, na osnovu sukcesivne obrade video snimaka cilja. Eksperimentalni rezultati pokazuju da se greške estimacije pozicije cilja kreću u granicama do $10 \mathrm{~m}$ na daljini do $5 \mathrm{~km}$, a da se sa približavanjem cilja smanjuju na 2 do $3 \mathrm{~m}$. Greške predikcije su nešto veće na početku praćenja, kada iznose do $20 \mathrm{~m}$ singularno, da bi se sa približavanjem cilja smanjivale na 2 do $5 \mathrm{~m}$.

Može se konstatovati da je ostvaren doprinos u postavci nove metode praćenja ciljeva, zasnovane isključivo na primeni video senzora. Pasivni video senzori se redovno primenjuju u sistemima PVO, uz upotrebu aktivnih senzora za određivanje daljine cilja. Mogućnosti njihove primene proširene su postavljanjem nove metode određivanja daljine cilja $i$ novog modela njegovog praćenja. Pri tome je izvršen optimalni izbor modela i parametara adaptacije paralelno primenjenih Kalmanovih filtera $u$ višemodelskom estimatoru. Rezultatima sprovedenih eksperimentalnih istraživanja uspešno je potvrđen izbor optimalnih rešenja adaptacije estimatora i mogućnosti praktične primene nove metode u sistemima upravljanja vatrom PVO. Poseban značaj ostvarenog naučnog doprinosa ogleda se $\mathrm{u}$ univerzalnosti postavljene metode $\mathrm{i}$ mogućnosti mnogo šire primene u oblasti automatizacije i robotike.

Dalja istraživanja potrebno je usmeriti ka unapređivanju postupaka obrade slike, merenja i estimacije pozicije objekata, kao i izučavanju mogućnosti primene metode za rešavanje specifičnih problema. 


\section{Literatura:}

[1] Ugarak, D.; Milinović, M.: Error and noise analyses and their influence on the air target tracking and coordinates estimation, Scientific Tehnical Review, Vol LIII, No.1, 2003.

[2] Ugarak, D.: Određivanje daljine cilja pomoću video senzora i analiza uticaja grešaka i šuma merenja, OTEH Vojna akademija, Beograd, 2005.
[3] Ugarak, D.: Ocena daljine cilja u toku praćenja video senzorima, OTEH Vojna akademija, Beograd, 2005.

[4] Milinović, M.: Modeliranje sistema upravljanja vatrom praćenja vazdušnih ciljeva, Mašinski fakultet, Beograd 2002.

[5] Blackman, S.: Design and Analysis of Modern Tracking Systems, Norwood, MA:Arteach House, 1999.

[6] Bar-Shalom, Y.: Estimation With Applications to Tracking and Navigation, John Wily \& Sons, New York, 2001. 